\title{
Antiviral drug resistance
}

\author{
Use the right antiviral drug and hit the virus hard
}

In the past few years we have witnessed the emergence of a new strand of antimicrobial treatment-antiviral drugs. Those currently available include amantadine (against influenza A virus), tribavirin (respiratory syncytial virus), ganciclovir (cytomegalovirus), aciclovir, valaciclovir, famciclovir, foscarnet (all active against the herpes viruses), and the antiretroviral drugs zidovudine, didanosine, and zalcitabine. Important advances have been made in reducing the incidence of life threatening opportunistic infections in recipients of transplants, successfully treating respiratory infections such as respiratory syncytial virus bronchiolitis and severe influenza $\mathrm{A}$, and more recently in dramatically reducing HIV viral load by combination antiretroviral therapy. Further targets of antiviral agents in the near future will include hepatitis $B$, hepatitis $C$ (interferons currently provide limited benefit for carriers of either virus), the common cold virus, and papillomaviruses. The impetus for and scientific rationale of antiviral drug development have been greatly enhanced by the HIV epidemic; at least five new antiretroviral drugs are near to licensing, in addition to the three currently available in Britain. The tremendous investment by the pharmaceutical industry in discovering antiviral drugs ensures a continued expansion in the antiviral armoury.

However, amid this euphoria the potential for antiviral drug resistance must not be forgotten. Viral resistance emerges against virtually all antiviral compounds, including the anti-herpes drugs aciclovir, ${ }^{1}$ ganciclovir, ${ }^{2}$ and foscarnet, ${ }^{3}$ the anti-influenza A drug amantadine (or the equivalent rimantidine), ${ }^{4}$ and all antiretroviral drugs. ${ }^{5}$ Many of these resistant strains of viruses have been shown to have mutations in the genes coding for the specific drug target or drug activator - for example, the viral thymidine kinase gene in herpes simplex resistant to aciclovir, and the reverse transcriptase gene in HIV resistant to zidovudine. Viruses such as HIV, which have a higher propensity to mutate during replication, are more liable to generate resistant variants than those with greater fidelity of replication, such as the herpes viruses, although this also depends on continued viral replication in the presence of the drug. We must expect that all new, virus specific antiviral drugs have the potential for selecting for drug resistant viruses.

What are the clinical and public health implications of antiviral drug resistance? Debilitating and life threatening drug resistant herpes virus infections (cytomegalovirus, varicella zoster virus, and herpes simplex virus) are well recognised in immunocompromised patients, including recipients of transplants; those with haematological malignancies; those receiving chemotherapy; and AIDS patients. ${ }^{6-8}$ These patients are increasingly subject to long courses of anti-herpes drug prophylaxis and treatment, and the emergence of resistance in this setting as a cause of drug failure is not surprising. Aciclovir resistant herpes viruses are likely to be cross resistant to valaciclovir and famciclovir, the newer anti-herpes drugs, and foscarnet remains the only option as second line treatment in most cases. ${ }^{9}$ Ideally, virus isolates should be assessed for antiviral susceptibilities to confirm virological resistance, but facilities for such testing have not been widely available. Hitherto, herpes simplex virus and varicella zoster virus resistant to aciclovir have not been noted in immunocompetent patients. However, the use of aciclovir, famciclovir, and valaciclovir for treating herpes simplex and varicella zoster virus infections in the community is increasing and requires parallel monitoring for emergence of resistance.

HIV drug resistance has been documented against all existing and soon to be licensed reverse transcriptase inhibitors, as well as a large number of the new class of protease inhibitors undergoing clinical trials. ${ }^{5}$ Emergence of drug resistance limits the efficacy of monotherapy against HIV, and this method of treatment will soon be superseded by combination antiretroviral therapy (cost withstanding), such as two reverse transcriptase inhibitors plus a protease inhibitor. Interestingly, one of the most promising drugs in such combinations is 3TC (lamivudine), which also shows excellent activity against hepatitis $B,{ }^{10}$ as does the new anti-herpes drug famciclovir. ${ }^{11}$ This raises the hope of significant advances in the management of what remains one of the major infectious causes of morbidity and mortality worldwide. However, resistance of hepatitis B virus to lamivudine has already been documented in ongoing clinical trials. ${ }^{12}$ By analogy with the treatment of HIV, combination approaches may be required to secure long term suppression of hepatitis $B$ virus.

Person to person transmissibility of resistant virus has been clearly demonstrated for influenza A resistant to rimantidine and HIV resistant to zidovudine. ${ }^{4}$ Transmission of zidovudine resistant strains of HIV between users of injected drugs, through inoculation accidents, and from mother to baby have also been documented, and there is preliminary evidence for an increase in the prevalence of zidovudine resistant HIV among untreated patients in some communities. ${ }^{13}$ Little information is available about transmissibility of drug resistant herpes viruses, and this possibility should be investigated in well designed structured studies.

By early in the next century, antiviral drugs will have assumed an importance similar to that held by antibiotics over the previous 50 years. It is vital that the use of antiviral drugs 
be guided by results of well designed controlled trials and laboratory monitoring. Clinicians are likely to minimise the emergence of resistance by hitting the virus hard with adequate dosing regimens. Clinical failure of antiviral therapy in the presence of high drug levels may be due to drug resistance, and second line therapy should then be considered.

Since we now recognise the potential for antiviral compounds to generate viral resistance, it would be foolish not to monitor carefully the current and future use of these drugs, if only to ensure that they are prescribed appropriately, to maximum patient benefit and with minimal risk to the population at large. In response to these concerns the Public Health Laboratory Service, in collaboration with the University of Birmingham, has recently announced the setting up of an antiviral susceptibility reference laboratory to undertake

1 Erlich KS, Mills J, Chatis P, Mertz GJ, Busch DF, Follansbee SE, et al. Acyclovir-resistant herpes simplex virus infections in patients with the acquired immunodeficiency syndrome. $N$ Engl F Med 1989;320:293-6.

2 Stanat SC, Reardon JE, Erice A, Jordan MC, Drew WL, Biron KK. Ganciclovir-resistance cytomegalovirus clinical isolates: mode of resistance to ganciclovir. Antimicrob Agents Chemother 1991;35:2191-7.

3 Safrin S, Kimmerley S, Plotkin B, Smith T, Weissbach N, De Varenez D, et al. Foscarnet-resistant herpes simplex infection in patients with AIDS. I Infect Dis 1994;169:193-6.

4 Hayden FG, Belsh RB, Clover RD, May AJ, Oakes MJ, Soo W. Emergence and apparent transmission of rimantidine resistant influenza A virus. N Engl f Med 1989;321:1696-702.

5 Mellors JW, Larder BA, Schinaza RF. Mutations in HIV-1 reverse transcriptase and protease associated with drug resistance. Int Antivir Neww 1995;3:8-12.

6 Lungman P, Llungman P, Ellis MN, Hackman RL, Shepp DH, Meyers JD. Acyclovir-resistant Lungman P, Lungman P, Ellis MN, Hackman RL, Shepp DH, Meyers JD. Acyclovir-resistant
herpes simplex causing pneumonia after marrow transplantation. $\mathcal{O}$ Infect Dis 1990;162:144-8. 7 Erice A, Chou S, Biron KK, Stanat SC, Balfour HH Jr, Jordan MC. Progressive disease due to ganciclovir-resistane cytomegalovirus in immunocompromised patients. N Engl $f \mathrm{Med}$ 1989;320:289-93. surveillance for resistance to existing and new drugs, assess the public health implications of resistance, and provide a readily available service of diagnostic assays to assess viral susceptibilities to drugs.

DEENAN PILLAY Head

Public Health Laboratory Service Antiviral Susceptibility

Reference Laboratory,

Birmingham Public Health Laboratory,

Birmingham Heartlands Hospital,

Birmingham B9 5SS

ALISDAIR M GEDDES

Professor

Department of Infection,

University of Birmingham Medical School,

Birmingham B15 2TJ
8 Snoeck R, Gerard M, Sadzot-Delvaux C, Andrei G, Balzarini J, Reynen D, et al. Meningoradiculonecuritis due to aciclovir-resistant varicella zoster virus in an acquired immunodeficiency syndrome patient. F Med Virol 1994;42:338-47.

9 Safrin S, Crumpacker C, Chatis P Davis R, Hafner R, Rush J, et al. A controlled trial comparing foscarnet with vidarabine for acyclovir-resistant mucocutaneous herpes simplex in the acquired immunodeficiency syndrome. N Engl f Med 1991;325:551-5.

10 Dienstag JL, Perrillo RP, Schiff ER, Bartholomew M, Vicary C, Rubin M. A preliminary trial of lamivudine for chronic hepatitis B infection. N Engl F Med 1995;333:1657-61.

11 Main J, Brown JL, Howells C, Galassini R, Crossey M, Karayiannis P, et al. A double blind, placebo-controlled study to assess the effect of famciclovir on virus replication in patients with chronic hepatitis B virus infection. I Viral Hepatitis 1996;3:211-5.

12 Ling R, Mutimer D, Ahmed M, Boxall EH, Elias E, Dusheiko GM, et al. Selection of mutation in the hepatitis $B$ virus polymerase during the therapy of transplant patients with lamivudine. Hepatology (in press).

13 Pineda JA, Rubio A, Leal M, Reg C, Olivera M, Sanchez-Quijano, et al. Frequency of appearance of primary 215-mutation in HIV-1 virus on antiviral naive patients during the last eight years. Antiviral Therapy (in press).

\section{The NHS reforms revisited}

\section{Health care systems change as societies change}

Born amid anger and bitterness, the 1991 reforms of the NHS continue to be a subject of controversy. No consensus about the balance of costs and benefits has emerged, and disagreement about the NHS will doubtless feature as prominently in the next general election campaign as it did in the previous two. Not only is the available evidence about the NHS's record since 1991 fragmentary and often ambiguous, but the fiercely partisan positions taken up by advocates and critics when Kenneth Clarke launched Working for Patients ${ }^{1}$ in 1989 suggest that, even if more had been invested in evaluation, any further evidence would have been used to fuel argument rather than to resolve it.

It is therefore bold of the BBC to launch its three-part television series Safe with Us, designed to document the genesis, implementation, and impact of the NHS reforms. The series, to be screened over the next three weeks, illustrates both the strengths and weaknesses of television when tackling issues of public policy. Nothing can match television's ability to recreate political conflict. Facing the television cameras, Kenneth Clarke and the BMA leadership refight and reflect on their battles, while the newsreel images of protesting nurses and doctors convey the near hysterical atmosphere of the time.

The second programme, dealing with the implementation of the changes, has less overt drama to feed off. But, as the programme reminds us, conflict did not end with the enactment of the legislation. Consultants were bitterly divided about hospitals adopting trust status-first wave fundholders, as one of their number recalled, were treated like "Christians in the arena" by their colleagues. In short, the new NHS was launched in an atmosphere of acrimonious turbulence, with even its sponsors worried about the feasibility of making the internal market work. It is a story well told by the programme, exploiting to the full the ability of television to use the words of the participants to provide the script.

But in attempting to draw up some sort of balance sheet in the third programme, the makers of Safe with Us faced a rather different problem. Here there was no simple story of conflict to tell but a complex set of issues to explore. Instead, the programme chose to extract a simple theme from the welter of evidence: that, while the reforms had not destroyed the NHS, they had redefined it. The result is oversimplification, teetering on the edge of misrepresentation. For example, the expansion of private sector activity is emphasised, with no mention of the fact that the main expansion took place long before $1991 .^{2}$ Similarly, rationing in the contemporary NHS is stressed, with no recognition that this has been a feature of the service since $1948 .^{3}$

Drawing up a balance sheet of the NHS reforms has baffled many academics, ${ }^{4}$ so it may be unfair to criticise the makers of Safe with Us too harshly. Instead, perhaps, we should reflect on some of the wider implications of the programmes. First, the very fact that the post-1991 NHS has not solved many of the problems that it inherited-that it has disappointed the expectations of its advocates, just as it has disproved many of the fears of its critics-suggests that further change is likely. The pressures that generated Mrs Thatcher's reforms have not disappeared. Second, the story of the NHS reforms suggests that we should be thinking more about the process of change. Is conflict the inevitable price of introducing radical change in health care, as in 1948 and 1991, or is it possible to reach a consensus about desirable reform?

Neither of these issues is likely to be resolved in the context of health care policy. There may be a danger, as the editor of the $B M F$ points out in the third programme, that the NHS will become the system of last resort for the least well off. But this 